\title{
Stres Kerja, Insentif, Kepuasan Pengguna Bepengaruh terhadap Kinerja Sistem Informasi Akuntansi
}

\author{
Destha Della Pragaswari ${ }^{1}$ \\ Fakultas Ekonomi dan Bisnis \\ Universitas Udayana, Indonesia \\ Email: desthadella60@gmail.com
}

\author{
Ni Luh Sari Widhiyani ${ }^{2}$ \\ Fakultas Ekonomi dan Bisnis \\ Universitas Udayana, Indonesia
}

\begin{abstract}
ABSTRAK
Sistem informasi akuntansi yang digunakan bersifat luas, hal tersebut dapat memungkinkan terjadinya perangkapan tugas yang dialami oleh pegawai menimbulkan stres kerja, pemberian insentif yang tidak sesuai dengan beban tugas yang diberikan kepada pegawai serta adanya rasa kurang puas pengguna terhadap sistem informasi yang digunakan. Tujuan penelitianini adalah untuk mengetahui pengaruh stres kerja, insentif, kepuasan pengguna terhadap kinerja sistem informasi akuntansi. Sampel adalah pegawai pengguna sistem informasi akuntansi di Bapenda Kota Denpasar. purposive sampling digunakan dengan 60 responden dan dianalisis dengan regresi linear berganda. Penelitian ini menemukan Variabel stres kerja dapat menurunkan kinerja sistem informasi akuntansi, Variabel insentif dan kepuasan pengguna dapat meningkatkan kinerja sistem informasi akuntansi. 58,2\% variasi kinerja sistem informasi akuntansi dipengaruhi oleh ketiga variabel bebas dan 41,8\% dipengaruhi oleh faktor lain.
\end{abstract}

Kata Kunci: $\quad$ Stres Kerja; Insentif; Kepuasan Pengguna; Kinerja Sistem Informasi Akuntansi.

\section{Job Stress, Incentives, nd User Satisfaction Affect The Performance of Accounting Information Systems}

\begin{abstract}
The accounting information system can enable the duplication of tasks experienced by employees to cause work stress, incentives that are not in accordance with the workload and the user's dissatisfaction with the information system used. Purpose of study are to determine the effect of work stress, incentives, user satisfaction on the performance of accounting information systems. The sample is the employee who uses the accounting information system in Bapenda Denpasar. purposive sampling is used with 60 respondents and analyzed by multiple linear regression. This study found, work stress variables can reduce the performance of accounting information systems, incentives and user satisfaction can improve the performance of accounting information systems. $58.2 \%$ variation in accounting information system performance is influenced by all three independent variables and $41.8 \%$ is influenced by other factors.
\end{abstract}

Keywords: Job Stress; Incentives; User Satisfaction; Accounting Information System Performance.

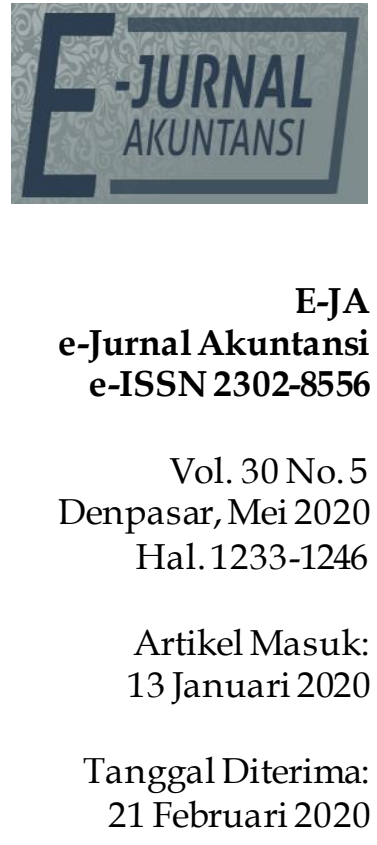

21 Februari 2020 


\section{PENDAHULUAN}

Berkembangnya teknologi informasi mengalami peningkatan yang pesat dalam segala bidang. Perkembangan teknologi yang sangat cepat ini dapat meningkatkan kualitas informasi sehingga akan meningkatkan kinerja sistem informasi akuntansi. Pesatnya perkembangan teknologi informasi ini telah menyebabkan bergantinya sistem informasi yang pada mulanya manual ke sistem yang berbasis komputer. Penerapan serta pemanfaatan sistem informasi yang berbasis komputer akan memudahkan untuk menghadapi persaingan di era globalisasi (Grande et al., 2011).

Kinerja sistem informasi merupakan salah satu faktor utama suatu keberhasilan pelaporan informasi perusahaan, karena itu pengguna sistem harus menguasai teknologi yang diterapkan dalam bidang pekerjaanya untuk mengetahui tingkat pencapaian tujuan organisasi (George et al., 2012). Penyediaan laporan keuangan yang relevan menjadi dasar dalam pengambilan keputusan merupakan hasil peningkatan kinerja sistem informasi akuntansi. Dalam sudut pandang akuntansi, hal tersebut merupakan tolak ukur untuk mengetahui seberapa besar kinerja sistem informasi akuntansi (Putra, 2016).

Salah satu cara yang dapat digunakan untuk dapat meningkatkan kinerja yaitu dengan rendahnya stres kerja yang dimiliki. Stres kerja merupakan suatu keadaan dimana seseorang mengalami ketegangan karena kondisi yang mempengaruhinya, kondisi tersebut dapat timbul dari dalam diri seseorang maupun dari lingkungan (Sliter \& Yuan, 2015). Seseorang memiliki tingkat stres yang tinggi terhadap pekerjaannya akan menimbulkan penurunan pada kinerja sistem informasi akuntansi (Jati \& Cahyana, 2017). Penelitian oleh Massie et al. (2018) menunjukkan stres kerja negatif terhadap kinerja sistem informasi akuntansi dikarenakan bahwa jika stres kerja meningkat maka akan mengurangi hasil dari kinerja sistem informasi akuntansi dikarenakan adanya target kerja sehingga pegawai harus melakukan lembur. Namun, penelitian Oemar \& Gangga (2017) menunjukkan stres kerja berpengaruh positif terhadap kinerja sistem informasi akuntansi.

Pemeberian insentif yang sesuai menjadi salah satu cara untuk meningkatkan kinerja sistem informasi akuntansi dalam menghasilkan pelaporan keuangan yang berkualitas (Kuvaas et al, 2018). Penelitian oleh Widhawati \& Damayanthi (2018) menunjukkan insentif berpengaruh positif terhadap kinerja sistem informasi akuntansi, dikarenakan pegawai akan mencoba untuk lebih baik lagi dalam bekerja mengingat adanya balas jasa dalam bentuk insentif yang diberikan perusahaan sesuai dengan hasil dan prestasi kerja yang dicapai. Namun, penelitian yang dilakukan Irustami dan Pasaribu (2015) menunjukan insentif tidak berpengaruh terhadap kinerja sistem informasi akuntansi.

Kepuasan pengguna merupakan sikap emosional individu atau tendensi terhadap pekerjaan (Wang et al. 2012). Kepuasan pengguna dapat diartikan sebagai tingkat kesukaan seseorang pengguna atas sistem aplikasi khusus yang digunakan dalam meningkatkan kinerja mereka di dalam organisasi (Konečnik et al. 2014). Penelitian yang dilakukan oleh Adi et al. (2017) menyatakan bahwa kepuasan pengguna berpengaruh positif terhada kinerja sistem informasi akuntansi disatuan kerja perangkat daerah, artinya bahwa dengan semakin 
puasnya seorang pengguna, belum tentu semakin meningkat kinerjanya dalam pelaksanaan tugas- tugas. Namun, penelitian yang dilakukan oleh Yasri, (2016) yang menyatakan bahwa kepuasan pengguna tidak berpengaruh positif terhadap kinerja sistem informasi akuntansi di Bank Nagari.

Pemerintah Kota Denpasar pada pertengahan tahun 2010 telah menerapkan Sistem Informasi Manajemen Daerah (SIMDA). Demi keseragaman dalam sistem pengelolaan keuangan daerah Pemerintah Kota Denpasar menggantikan SIMDA menjadi Sistem Informasi Pengelolaan Keuangan Daerah (SIPKD). Pemerintah Kota Denpasar menerapkan SIPKD dan kemudian melakukan penyesuaian terhadap penerapan SIPKD pada awal bulan Januari 2011. Dengan adanya sistem baru yang diterapkan, pemerintah menginginkan terjadinya peningkatan dalam pengolahan data keuangan yang diharapkan berjalan dengan efektif dan memberikan hasil yang akurat.

Tabel 1. Penerimaan Pendapatan Asli Daerah (PAD) Kota Denpasar dari Tahun 2014-2018 (dalam ribuan rupiah)

\begin{tabular}{lll}
\hline Tahun & Target $(\mathrm{Rp})$ & Realisasi $(\mathrm{Rp})$ \\
\hline 2014 & 644.117 .977 & 698.705 .007 \\
2015 & 724.497 .965 & 776.176 .266 \\
2016 & 740.366 .097 & 834.296 .740 \\
2017 & 932.703 .422 & 1.008 .694 .123 \\
\hline
\end{tabular}

Sumber: Bapenda Kota Denpasar, 2017

Badan Pendapatan Daerah Kota Denpasar merupakan unit kerja yang mempunyai tugas pokok serta mengkoordinasi penerimaan pendapatan asli daerah Kota Denpasar yang Pendapatan Asli Daerah (PAD) dapat bersumber dari pajak daerah, retribusi daerah, hasil pengelolaan kekayaan daerah yang tidak dipisahkan, serta lain-lain PAD yang sah. Dalam merealisasikan bersama dengan satuan kerja terkait sesuai dengan tahapan yang telah ditetapkan sehingga dapat dipergunakan untuk membiayai rencana kegiatan. Ditinjau dari besarnya realisasi penerimaan pendapatan anggaran daerah menunjukan bahwa terjadinya perkembangan. Perkembangan realisasi pendapatan anggaran daerah ditunjukan pada Tabel 1.

Berdasarkan Tabel 1. menunjukan bahwa realisasi penerimaan pendapatan anggaran daerah yang dimiliki oleh Bapenda Kota denpasar meningkat setiap tahunnya, secara tidak langsung membutuhkan kinerja sistem infomasi akuntansi yang efisien dalam pengelolaan data. Berdasarkan survei pendahuluan beberapa hal yang perlu diperhatikan diantaranya: terjadinya perangkapan tugas pada pegawai membuat pekerjaan yang sudah diberikan tidak selesai dengan tepat waktu serta memicu terjadinya beban kerja yang ditandai dengan terjadinya stres kerja, pemeberian insentif yang tidak merata dan tidak sesuai dengan jumlah pekerjaan yang telah dibebankan serta sistem yang digunakan perlu adanya pembaharuan sistem informasi akuntansi sehingga pengguna mudah dalam megoperasikan dan memberikan kepuasan terhadap pengguna sehingga tidak terjadi human eror yang mengakibatkan pegawai kesulitan dalam mengelola sistem informasi akuntansi.

Berdasarkan latar belakang diatas adanya stres kerja yang dialami oleh pegawai, pemberian insentif yang tidak sesuai dengan beban tugas yang diberikan serta kepuasan pengguna terhadap sistem informasi yang digunakan, 
sehingga pemrosesan dan pengelolaan sistem informasi akuntansi yang dapat menurunkan atau meningkatkan kinerja sistem informasi akuntansi. Keberhasilan suatu perusahaan atau sebuah instansi sangat dipengaruhi oleh kinerja sistem informasi akuntansi dalam pengolahan data keuangan yang diharapkan dapat berjalan dengan efektif dan efisien. Pelitian tentang kinerja sistem informasi akuntansi sebelumnya telah banyak dilakukan, tetapi memperoleh hasil yang berbeda-beda atau tidak konsisten.

Stres kerja merupakan perasaan tertekan yang dialami individu dalam menghadapi pekerjaan yang disebabkan oleh faktor lingkungan kerja seperti lingkungan, organisasi, dan individu. Stres kerja dapat berdampak salah dan menyebabkan penurunan kinerja. Hal ini berarti bahwa stres mempunyai potensi dalam menurunkan pelaksanaan kinerja (Cleary, 2017). Tingkat stres tinggi maka akan timbulnya hambatan dalam operasional kerja, keterlambatan penyelesaian tugas dan menurunnya kualitas yang dihasilkan kinerja sistem informasi akuntansi.

Penelitian yang dilakukan Christine (2016) menyatakan bahwa stres kerja berpengaruh negatif terhdap kinerja sistem informasi akuntansi. Penelitian yang sama dilakukan oleh Lanny et al. (2017) , Esmeray (2016), Hamdan (2015) dan Rahayu et al. (2017) yang menemukan bahwa stres kerja berpengaruh negatif terhadap kinerja sistem informasi akuntansi hal tersebut dikarenakan tingkat stres kerja yang paling dominan disebabkan oleh beban kerja yang telalu banyak sehingga menjadikan penurunan kualitas dari kinerja sistem informasi akuntasi. Berdasarkan uraian tersebut, maka hipotesis penelitian sebagai berikut:

$\mathrm{H}_{1}$ : Stres kerja berpengaruh negatif pada kinerja sistem informasi akuntansi.

Pada umumnya insentif yang diberikan dapat memotivasi dalam meningkatkan produktifitas perusahaan, sehingga dapat memanfaatkan laporan yang dihasilkan dari kinerja sistem informasi akuntansi yang kemungkinan memiliki kecenderungan pegawai bekerja seadanya sehingga pekerjaan yang dilakukannya tidak optimal. Hal tersebut membuat sebagian besar pimpinan memberikan insentif kepada karyawan guna untuk membuat kinerja sistem informasi akuntansi yang dihasilkan baik dan berdampak pada akuratnya kualitas informasi yang dihasilkan perusahaan (Dewintha et al. 2018).

Penelitian yang dilakukan Nurani (2015) menyatakan bahwa insentif berpengaruh positif terhadap kinerja sistem informasi. Penelitian yang sama dilakukan oleh Maziah (2017), Ernawatiningsih \& Kepramareni (2019), Malinda et al. (2019) Santoso ( 2016) serta Veronica et al. (2018) dalam penelitiannya insentif berpengaruh positif terhadap kinerja sistem informasi akuntansi dikarenakan pentingnya pemberian insentif untuk meningkatkan hasil kinerja sistem informasi akuntansi. Berdasarkan uraian tersebut, maka hipotesis penelitian:

$\mathrm{H}_{2}$ : Insentif berpengaruh positif pada kinerja sistem informasi akuntansi.

Kinerja sistem informasi akuntansi merupakan pendapat pengguna atas sistem aplikasi khusus yang digunakan dalam meningkatkan kinerja mereka dalam organisasi. Kemudahan yang diberikan sistem informasi membuat pengguna merasa puas terhadap sistem yang digunakan, maka akan cenderung untuk merasa nyaman ketika sedang melakukan pekerjaan dengan mengoperasikan sistem tersebut, sehingga berdampak pada pengguna yang 
merasa terbantu dalam menyelesaikan tugasnya dan dapat meningkatkan kinerja sistem informasi akuntansi sehingga kualitas informasi dan dapat mengambil keputusan secara akurat.

Penelitian yang dilakukan oleh Hutabarat (2016) dan Rosanty et al. (2017) yang menyatakan bahwa kepuasan pengguna sistem informasi akuntansi berpengaruh positif terhadap kinerja sistem informasi akuntansi. Penelitian yang sama dilakukan oleh Rachmawati \& Mulyani (2016), Budyastuti (2019), Mukherjee (2018), Arisman \& Fuadah (2017), Nurhayati \& Koesdiningsih (2018), Kurniawati et al. (2017) dan Saputra et al. (2018) bahwa kepuasan pengguna sistem informasi akuntansi berpengaruh terhadap kinerja sistem informasi akuntansi. Kepuasan pengguna sistem informasi akuntansi dapat dilihat umpan balik dan sikap pengguna yang setelah mengoperasikan sistem tersebut. Sikap pengguna terhadap penggunaan sistem informasi akuntansi dapat menjadikan evaluasi mengenai seberapa puas pengguna tersebut menggunakan sitem informasi akuntansi. Berdasarkan uraian tersebut, maka hipotesis penelitian:

$\mathrm{H}_{3}$ : Kepuasan pengguna berpengaruh positif pada kinerja sistem informasi akuntansi.

\section{METODE PENELITIAN}

Penelitian yang dilakukan dalam penelitian ini adalah metode kuantitatif. Penelitian ini dilakukan dengan mengambil wilayah pengujian di Bapenda Kota Denpasar dikarenakan secara umum permasalahan disebabkan kurangnya pengelolaan sistem informasi akuntansi sehingga dalam mengelola pendapatan daerah tidak salah dalam merealisasikannya. Obyek dalam penelitian ini adalah kinerja pengguna sistem informasi akuntansi Bapenda Kota Denpasar yang terlibat dalam penggunaans istem informasi akuntansi. Faktor yang diteliti adalah stres kerja, insentif serta kepuasan pengguna. Variabel bebas dalam penelitian ini adalah stres kerja $\left(X_{1}\right)$, insentif $\left(X_{2}\right)$, kepuasan pengguna $\left(X_{3}\right)$. Variabel terikat dalam penelitian ini adalah kinerja sistem informasi akuntansi (Y).

Stres kerja dalam penelitian ini merupakan kondisi seseorang yang memiliki kendala atau tuntutan yang dikaitkan dengan apa yang diinginkan dan hasilnya akan bersifat buruk dan tidak menentu. Insentif dalam penelitian ini merupakan suatu cara untuk pembayaran upah pada pegawai yang akan berdampak pada produktivitas dan hasil dari kinerja sistem informasi akuntansi.Kepuasan pengguna dalam penelitian ini merupakan tolak ukur keberhasilan suatu sistem informasi. Kepuasan pengguna ini kemudian menjadi bagian dalam pengembangan model keberhasilan sistem informasi selanjutnya. Kinerja sistem informasi akuntansi dalam penelitian ini merupakan hasil kerja yang dicapai seseorang dalam melaksanakan tugas-tugas tyang dibebankan kepadanya didasarkan atas kecakapan, pengalaman dan waktu.

Populasi dalam penelitian ini adalah pegawai Bapenda Kota Denpasar yang berjumlah 225 orang. Metode yang digunakan dalam penentuan sampel dalam penelitian ini yaitu metode purposive sampling dengan 60 pegawai di Bapenda Kota Denpasar yang terlibat langsung dalam menggunakan sistem informasi akuntansi. Metode pengumpulan data yang digunakan dalam penelitian ini adalah kuesioner. Penelitian ini menggunakan pendekatan 
kuantitatif dengan metode penelitian penjelasan yang dalam pendekatan kuantitatif dapat diukur sehingga dapat menggunakan statistik dalam pengujiannya. Data kuantitatif dalam penelitian ini yaitu data-data hasil kuesioner yang disajikan dalam bentuk skala likert. Data pimer dalam penelitian ini adalah pertanyaan terstruktur dalam kuesioner dan hasil wawancara yang sifatnya tertutup dengan jawaban yang telah disediakan dan harus diisi oleh responden dengan cara memilih salah satu alternatif jawaban yang tersedia. Data sekunder dalam penelitian ini adalah data mengenai daftar jumlah pegawai di Bapenda Kota Denpasar.

\section{HASIL DAN PEMBAHASAN}

Penelitian ini dilakukan untuk mengetahui pengaruh stres kerja, insentif, kepuasan pengguna terhadap kinerja sistem informasi akuntansi. Ringkasan penyebaran dan pengembalian kuesioner dapat dilihat pada Tabel 2.

\section{Tabel 2. Rincian Pengiriman dan Pengembalian Kuesioner}

\begin{tabular}{ll}
\hline Keterangan & Jumlah \\
\hline Kuesioner yang disebar & 60 \\
Kuesioner yang tidak kembali & - \\
Kuesioner yang dikembalikan & 60 \\
$\begin{array}{l}\text { Kuesioner yang digunakan } \\
\text { Tingkat Pengembalian (Respons trate) }\end{array}$ & 60 \\
$\begin{array}{l}\text { Kuesioner yang dikembalikan 60/60 } 100 \% \\
\text { Tingkat Pengembalian yang digunakan (useable response rate) }\end{array}$ & $100 \%$ \\
Kuesioner yang diolah_60/60 x 100\% & $100 \%$ \\
\hline
\end{tabular}
Sumber: Data Penelitian, 2019

Berdasarkan Tabel 2. dapat dilihat bahwa jumlah kuesioner yang disebar pada penelitian ini sebanyak 60 eksemplar.

\section{Tabel 3. Karakteristik Responden}

\begin{tabular}{|c|c|c|c|c|}
\hline No & Karakteristik & Klasifikasi & $\begin{array}{l}\text { Jumlah } \\
\text { Responden } \\
\text { (orang) }\end{array}$ & $\begin{array}{l}\text { Persentase } \\
\text { Responden } \\
(\%)\end{array}$ \\
\hline \multirow[t]{2}{*}{1} & Jenis & Laki-laki & 36 & 60,0 \\
\hline & Kelamin & Perempuan & 24 & 40,0 \\
\hline \multicolumn{2}{|c|}{ Jumlah } & & 60 & 100 \\
\hline \multirow[t]{3}{*}{2} & Pendidikan & S1 & 51 & 85,0 \\
\hline & Terakhir & S2 & 7 & 11,7 \\
\hline & & S3 & 2 & 3,3 \\
\hline \multicolumn{2}{|c|}{ Jumlah } & & 60 & 100 \\
\hline \multirow[t]{3}{*}{3} & Lama Kerja & $<2$ tahun & 10 & 17,5 \\
\hline & & 2-10 tahun & 24 & 30,0 \\
\hline & & $>10$ tahun & 26 & 52,5 \\
\hline \multicolumn{2}{|c|}{ Jumlah } & & 60 & 100 \\
\hline
\end{tabular}

Sumber: Data Penelitian, 2019

Responden dalam penelitian ini yaitu dominan berjenis kelamin perempuan, artinya lebih banyak pegawai perempuan dibandingkan pegawai laki-laki yang bekerja pada Bapenda Kota Denpasar. Pegawai Bapenda Kota Denpasar dominan adalah lulusan Sarjana yang dianggap sudah mampu serta memadai untuk menjadi pegawai pemerintahan yang memiliki kompetensi demi 
meningkatkan kinerja. Sebagian besar pegawai yang bekerja di Bapenda Kota Denpasar memiliki masa kerja lebih dari 10 tahun yang artinya sudah memiliki pengalaman dalam menggunakan sistem informasi akuntansi.

Tabel 4. Hasil Uji Validitas

\begin{tabular}{|c|c|c|c|}
\hline Variabel & Indikator & Koefisien Korelasi & $\begin{array}{l}\text { Sig. } \\
\text { (2-tailed) }\end{array}$ \\
\hline \multirow[t]{5}{*}{ Stres Kerja $\left(\mathrm{X}_{1}\right)$} & $\mathrm{X}_{1.1}$ & 0,826 & 0,000 \\
\hline & $\mathrm{X}_{1.2}$ & 0,873 & 0,000 \\
\hline & $\mathrm{X}_{1.3}$ & 0,829 & 0,000 \\
\hline & $\mathrm{X}_{1.4}$ & 0,901 & 0,000 \\
\hline & $\mathrm{X}_{1.5}$ & 0,850 & 0,000 \\
\hline \multirow[t]{5}{*}{ Insentif $\left(X_{2}\right)$} & $X_{2.1}$ & 0,878 & 0,000 \\
\hline & $\mathrm{X}_{2.2}$ & 0,726 & 0,000 \\
\hline & $\mathrm{X}_{2.3}$ & 0,826 & 0,000 \\
\hline & $\mathrm{X}_{2.4}$ & 0,839 & 0,000 \\
\hline & $\mathrm{X}_{2.5}$ & 0,890 & 0,000 \\
\hline \multirow{3}{*}{$\begin{array}{l}\text { Kepuasan Pengguna } \\
\left(\mathrm{X}_{3}\right)\end{array}$} & $\mathrm{X}_{3.1}$ & 0,886 & 0,000 \\
\hline & $\mathrm{X}_{3.2}$ & 0,741 & 0,000 \\
\hline & $\mathrm{X}_{3.3}$ & 0,868 & 0,000 \\
\hline Kinerja Sistem Informasi & $\mathrm{Y}_{1}$ & 0,827 & 0,000 \\
\hline \multirow[t]{3}{*}{ Akuntansi $(Y)$} & $\mathrm{Y}_{2}$ & 0,841 & 0,000 \\
\hline & $\mathrm{Y}_{3}$ & 0,835 & 0,000 \\
\hline & $\mathrm{Y}_{4}$ & 0,911 & 0,000 \\
\hline
\end{tabular}

Sumber: Data Penelitian, 2019

Hasil uji validitas pada Tabel 4. menunjukkan bahwa seluruh instrumen penelitian yang digunakan tersebut valid dan layak digunakan sebagai instrument penelitian.

Tabel 5. Hasil Uji Reliabilitas

\begin{tabular}{lll}
\hline No. & Variabel & Cronbach's Alpha \\
\hline 1 & Stres Kerja $\left(\mathrm{X}_{1}\right)$ & 0,907 \\
2 & Insentif $\left(\mathrm{X}_{2}\right)$ & 0,889 \\
3 & Kepuasan Pengguna $\left(\mathrm{X}_{3}\right)$ & 0,780 \\
4 & Kinerja Sistem Informasi Akuntansi $(\mathrm{Y})$ & 0,876 \\
\hline
\end{tabular}

Sumber: Data Penelitian, 2019

Hasil uji reliabilitas yang disajikan dalam Tabel 5. menunjukkan bahwa seluruh instrumen penelitian memenuhi syarat reliabilitas.

Tabel 6. Hasil Uji Deskriptif

\begin{tabular}{llllll}
\hline Keterangan & N & Minimum & Maximum & Mean & $\begin{array}{l}\text { Std. } \\
\text { Deviation }\end{array}$ \\
\hline Stres Kerja & 60 & 12 & 19 & 13,60 & 1,968 \\
Insentif & 60 & 10 & 20 & 16,67 & 2,723 \\
Kepuasan Pengguna & 60 & 6 & 12 & 10,13 & 1,741 \\
$\begin{array}{l}\text { Kinerja Sistem } \\
\text { Informasi Akuntansi }\end{array}$ & 60 & 8 & 16 & 13,48 & 2,198 \\
Valid N (listwise) & 60 & & & & \\
\hline Sumber: Data Penelitian, & & & & & \\
\hline
\end{tabular}


Variabel stres kerja memiliki nilai minimum sebesar 9 dan nilai maksimum sebesar 19. Variabel stres kerja yang diukur dengan 5 item pernyataan dengan bantuan skala likert 4 poin memiliki nilai rata-rata sebesar 13,60 . Nilai sebesar 2,72 berada pada kriteria tinggi yaitu pada rentang nilai 2,51 t-3,25, maka dapat dikatakan bahwa stres kerja yang terjadi pada Bapenda Kota Denpasar yaitu inggi. Nilai standar deviasi variabel stres kerja sebesar 1,968. Hal ini berarti nilai standar deviasi lebih rendah dibandingkan dengan nilai rata-rata, yang artinya sebaran jawaban responden terkait dengan stres kerja sudah merata.

Variabel insentif yang diukur dengan 5 item pernyataan dengan bantuan skala likert 4 poin memiliki nilai rata-rata sebesar 16,67. Nilai sebesar 3,334 berada pada kriteria sangat tinggi yaitu pada rentang 3,26 - 4,00, maka dapat dikatakan bahwa insentif yang terjadi pada Bapenda Kota Denpasar yaitu sangat tinggi. Nilai standar deviasi variabel insentif sebesar 2,723. Hal ini berarti nilai standar deviasi lebih rendah dibandingkan dengan nilai rata-rata, yang artinya sebaran jawaban responden terkait dengan insentif sudah merata. Kriteria pengukuran tersebut menunjukkan bahwa semakin tinggi nilai rata-rata yang diperoleh menunjukkan semakin baik tanggapan responden terhadap item maupun variabel tersebut. Nilai 3,37 dikatakan bahwa kepuasan pengguna yang terjadi pada Bapenda Kota Denpasar yaitu sangat tinggi. Nilai standar deviasi variabel kepuasan pengguna sebesar 1,741. Hal ini berarti nilai standar deviasi lebih rendah dibandingkan dengan nilai rata-rata, yang artinya sebaran jawaban responden terkait dengan kepuasan pengguna sudah merata. Nilai rata-rata variabel kinerja sistem informasi akuntansi sebesar 3,37 dikatakan bahwa kinerja sistem tinformasi akuntansi yang terjadi pada Bapenda Kota Denpasar yaitu sangat tinggi. Nilai standar deviasi variabel sebesar 2,198. Hal ini berarti nilai standar deviasi lebih rendah dibandingkan dengan nilai rata-rata, yang artinya sebaran jawaban responden terkait dengan kinerja sistem informasi akuntansi sudah merata.

Tabel 7. Hasil Uji Normalitas

\begin{tabular}{ll}
\hline & Unstandardized Residual \\
\hline $\mathrm{N}$ & 60 \\
Kolmogorov-Smirnov Z & 0,121 \\
Asymp.Sig.(2-tailed) & 0,029 \\
\hline Sumber: Data Penelitian, 2019 &
\end{tabular}

Berdasarkan hasil uji normalitas pada Tabel 7. dapat dikatakan bahwa data terdistribusi secara normal, sehingga dapat disimpulkan bahwa model memenuhi asumsi normalitas.

Tabel 8. Hasil Uji Multikoleniaritas

\begin{tabular}{lll}
\hline Variabel & Tolerance & VIF \\
\hline Stres kerja $\left(X_{1}\right)$ & 0,742 & 1,348 \\
Insentif $\left(X_{2}\right)$ & 0,680 & 1,470 \\
Kepuasan Pengguna $\left(X_{3}\right)$ & 0,738 & 1,355 \\
\hline Sumber: Data Pen
\end{tabular}

Sumber: Data Penelitian, 2019

Berdasarkan Tabel 8. berarti model persamaan regresi bebas dari multikolinearitas. 
Tabel 9. Hasil Uji Heteroskedastisitas

\begin{tabular}{ll}
\hline Variabel & Signifikansi \\
\hline Stres kerja $\left(\mathrm{X}_{1}\right)$ & 0,503 \\
Insentif $\left(\mathrm{X}_{2}\right)$ & 0,227 \\
Kepuasan pengguna $\left(\mathrm{X}_{3}\right)$ & 0,460 \\
\hline
\end{tabular}

Sumber: Data Penelitian, 2019

Berdasarkan Tabel 9. menunjukkan bahwa seluruh variabel tersebut bebas dari heteroskedastisitas.

Tabel 10. Hasil Analisis Regresi Linier Berganda

\begin{tabular}{llllll}
\hline Model & \multicolumn{2}{l}{$\begin{array}{l}\text { Unstandardized } \\
\text { Coefficients }\end{array}$} & \multicolumn{2}{l}{$\begin{array}{l}\text { Standardized } \\
\text { Coefficients }\end{array}$} & \\
\cline { 2 - 5 } & $\mathrm{B}$ & Std. Error & Beta & T & Sig. \\
\hline 1 (Constant) & 6,845 & 2,331 & & 2,936 & 0,05 \\
Stres kerja & $-0,209$ & 0,087 & $-0,240$ & $-2,393$ & 0,20 \\
Insentif & 0,330 & 0,085 & 0,409 & 3,905 & 0,00 \\
Kepuasan Pengguna & 0,380 & 0,127 & 0,301 & 2,992 & 0,04 \\
R Square & 0,582 & & & & \\
F Statistik & 25,959 & & & & \\
$\quad$ Signifikansi Uji F & 0,000 & & & & \\
\hline
\end{tabular}

Sumber: Data Penelitian, 2019

Nilai konstanta sebesar 6,845 menyatakan bahwa apabila variabel stres kerja (X1), insentif (X2), kepuasan pengguna (X3) sama dengan nol, maka kinerja sistem informasi akuntansi $(Y)$ adalah sebesar 6,845 satuan. Nilai koefisien regresi dari stres kerja (X1) sebesar -0,209 menunjukan bahwa terdapat pengaruh negatif antara variabel stres kerja terhadap kinerja sistem informasi akuntansi sebesar -0,209. Hal ini berarti apabila variabel independen stress kerja meningkat sebesar 1 satuan dengan asumsi bahwa variabel bebas lainnya konstan, maka variabel kinerja sistem informasi akuntansi takan mengalami penurunan sebesar 0,209 .

Nilai koefisien regresi dari insentif (X2), sebesar 0,330 menunjukan bahwa terdapat pengaruh positif antara variabel insentif terhadap kinerja sistem informasi akuntansi sebesar 0,330. Hal ini berarti a pabila variabel independen insentif naik sebesar 1 satuan dengan asumsi bahwa variabel bebas lainnya konstan, maka variabel kinerja sistem informasi akuntansi akan mengalami peningkatan sebesar 0,330. Nilai koefisien regresi dari kepuasan pengguna (X3) sebesar 0,380 menunjukan bahwa terdapat pengaruh positif antara variabel kepuasan pengguna terhadap kinerja system informasi akuntansi sebesar 0,380. Hal tini berarti apabila variabel independen kepuasan pengguna (X3) naik sebesar 1 satuan dengan asumsi bahwa variabel bebas lainnya konstan, maka variabel kinerja sistem informasi akuntansi $(Y)$ akan mengalami peningkatan sebesar 0,380 satuan. Nilai R Square sebesar 0,582 hal ini berarti 58,2\% variasi kinerja sistem informasi akuntansi (Y) dipengaruhi oleh variabel stres kerja (X1), insentif (X2), kepuasan pengguna (X3), sisanya sebesar 41,8\% dipengaruhi oleh faktor lain di luar model.

Berdasarkan hasil analisis regresi pada Tabel 9. variabel independen berpengaruh serempak (simultan) terhadap variabel dependen. Signifikansi F sebesar 0,000 lebih kecil dari 0,05. Hasil uji $\mathrm{F}$ yang di analisis dengan menggunakan program SPSS diperoleh nilai F hitung sebesar 25,959 dengan 
signifkansi sebesar 0,000<0,05, maka dapat disimpulkan bahwa pada kelompok yang diuji memiliki perbedaan yang nyata (signifikan). Hasil ini mempunyai arti bahwa ada pengaruh signifikan antara stres kerja, insentif, kepuasan pengguna terhadap kinerja sistem informasi akuntansi pada Bapenda Kota Denpasar.

Stres kerja merupakan suatu keadaan yang mempengaruhi emosi, proses berfikir dan kondisi seorang pegawai dan berdampak pada kinerja yang dihasilkan. Berdasarkan hasil pengujian (uji t) dalam penelitian ini, menunjukkan bahwa hipotesis pertama $\left(\mathrm{H}_{1}\right)$ stres kerja mempunyai pengaruh yang negatif terhadap kinerja sistem informasi akuntansi. Hal ini berarti bahwa semakin tinggi stres kerja menyebabkan penurunan kinerja sistem informasi akuntansi pada Bapenda Kota Denpasar. Stres kerja yang dialami oleh pegawai yang disebabkan karena adanya perangkapan tugas oleh pegawai, hal tersebut membuat pegawai kurang efisien dalam pengelolaan serta pengoperasian sistem informasi akuntansi dan berdampak pada penurunan terhadap kualitas kinerja sistem informasi akuntansi serta pelaporan hasil kerja yang tidak tepat waktu. Jika perangkapan tugas bisa diatasi dengan baik, maka sistem tersebut bisa dimanfaatkan dengan baik oleh pegguna, sehingga akan menimbulkan kemudahan dalam penggunaan sistem tersebut dan dapat menurunkan stres kerja dan terjadinya peningkatan kinerja sistem informasi akuntansi yang dihasilkan. Hasil tini mendukung penelitian yang dilakukan oleh Christine (2016) Lanny et al. (2017) dan Rahayu et al. (2017) yang menyatakan bahwa stres kerja berpengaruh negatif dan signifikan terhdap kinerja sistem informasi akuntansi hal tersbut dikarenakan ingkat stres kerja yang paling dominan disebabkan oleh beban kerja yang terlalu banyak sehingga menjadikan penurunan kualitas dari kinerja sistem informasi akuntasi.

Insentif merupakan suatu keadaan yang mempengaruhi emosi, proses berfikir dan kondisi seorang pegawai dan berdampak pada kinerja yang dihasilkan. Berdasarkan hasil pengujian (uji t) dalam penelitian ini, didapatkan menunjukkan bahwa hipotesis kedua $\left(\mathrm{H}_{2}\right)$ insentif mempunyai pengaruh yang positif terhadap kinerja sistem informasi akuntansi. Hal ini berarti bahwa semakin tinggi pemberian insentif yang diterima, maka dapat meningkatkan kinerja sistem informasi akuntansi pada Bapenda Kota Denpasar. Pemberian insentif yang sesuai dengan kapasitas kerja pegawai Bapenda Kota Denpasar merupakan salah satu cara untuk memotivasi dan mendorong pegawai, sehingga dalam diri mereka timbul semangat yang lebih besar untuk memberikan peningkatan kualitas dari kinerja sistem informasi akuntansi sehingga informasi yang diberikan reliabel dan korporatif. Hasil penelitian ini mendukung penelitian yang dilakukan oleh Nurani (2015) Maziah (2017) Santoso (2016) serta Veronica et al. (2018) dalam penelitiannya insentif berpengaruh positif terhadap kinerja sistem informasi akuntansi dikarenakan perlunya pemberian insentif untuk memotivasi karyawan sehingga dapat meningkatkan hasil kinerja sistem informasi akuntansi.

Kepuasan pengguna merupakan suatu keadaan yang mempengaruhi emosi, proses berfikir dan kondisi seorang pegawai dan berdampak pada kinerja yang dihasilkan. Berdasarkan hasil pengujian (uji t) dalam penelitian ini menunjukkan bahwa hipotesis ketiga $\left(\mathrm{H}_{3}\right)$ yaitu kepuasan pengguna mempunyai pengaruh yang positif terhadap kinerja sistem informasi akuntansi. Hal ini 
berarti bahwa semakin puas pengguna mengoperasikan sistem yang digunakan maka menyebabkan peningkatan kinerja sistem. Hasil penelitian ini sejalan dengan penelitian yang dilakukan oleh Hutabarat (2016) dan Rosanty et al. (2017) Kurniawati et al. (2017) dan Saputra et al. (2018) yang menyatakan kepuasan pengguna sistem informasi akuntansi berpengaruh terhadap kinerja sistem informasi akuntansi. Kepuasan pengguna sistem informasi akuntansi dapat dilihat umpan balik dan sikap pengguna yang setelah mengoperasikan sistem tersebut. Jadi Sikap pengguna terhadap penggunaan sistem informasi akuntansi dapat menjadikan evaluasi mengenai seberapa puas pengguna tersebut.

Penelitian yang dilakukan diharapkan dapat memberikan hasil mengenai analisis faktor - faktor yang mempengaruhi kinerja sistem informasi akuntansi pada Bapenda Kota Denpasar. Hasil uji hipotesis dalam penelitian ini ditemukan bahwa stres kerja memiliki pengaruh negatif sedangkan insentif, dan kepuasan pengguna, secara statistik memiliki pengaruh yang positif pada kinerja sistem informasi akuntansi pada Bapenda Kota Denpasar, sehingga hal tersebut membuktikan bahwa terjadinya perangkapan tugas, pemberian insentif yang tidak sesuai serta kepuasan pengguna terhadap kinerja sistem informasi dapat menurunkan ataupun meningkatkan kinerja sistem informasi dan sesuai dengan kajian penelitian terdahulu dan sesuai dengan teori Technology Acceptance Model (TAM).

Penelitian ini memberikan implikasi bagi Bapenda Kota Denpasar sebagai pertimbangan dan pengetahuan mengenai kinerja sistem informasi akuntansi serta faktor-faktor yang mempengaruhi. Instansi juga dapat memperhatikan stres kerja, insentif, maupun kepuasan pengguna, karena hal tersebut dapat memnimbulkan terjadinya penurunan atau peningkatan kinerja sistem informasi takuntansi pada Bapenda Kota Denpasar.

\section{SIMPULAN}

Stres kerja berpengaruh negatif terhadap kinerja sistem informasi akuntansi, yakni berarti semakin tinggi stres kerja yang dimiliki pegawai Bapenda Kota Denpasar maka kinerja yang dihasilkan akan semakin menurun yang berdampak pada penurunan kualitas laporan yang dihasilkan. Insentif berpengaruh positif terhadap kinerja sistem informasi akuntansi, yakni berarti semakin tinggi insentif yang diberikan pada pegawai Bapenda Kota Denpasar maka kinerja yang dihasilkan akan semakin meningkat yang berdampak pada motivasi kerja pegawai untuk menghasilkan kualitas informasi yang lebih baik. Kepuasan pengguna berpengaruh positif terhadap kinerja sistem informasi akuntansi, yakni berarti semakin tinggi kepuasan pengguna menggunakan sistem informasi akuntansi maka kinerja yang dihasilkan akan semakin meningkat yang berdampak pada kemudahan dalam mengoperasikan sistem informasi akuntansi.

Perlunya menjalin komunikasi yang baik dengan para pegawainya sehingga tidak ada konflik kerja yang terjadi antar pegawai dan dapat terjalin hubungan yang baik serta tidak akan berpengaruh terhadap kinerja sistem informasi akuntansi. Perlu adanya pemberian insentif yang adil sesuai dengan kuantitas dan kualitas kerja pegawai, karena dengan adanya pemberian insentif tersebut dapat memberikan motivasi terhadap para pegawai. Perlu adanyanya 
kesadaran para pegawai untuk dapat menyelesaikan tugas dengan tepat waktu dan tidak ada keterlambatan proses dalam pengambilan keputusan sehingga dapat meningkatkan kinerja sistem informasi akuntansi di Bapenda Kota Denpasar.

\section{REFERENSI}

Adi, I. W. A., Suardikha, I. M. S., \& Putri, I. G. A. M. A. D. P. (2017). Pengaruh Komitmen Organisasi, Budaya Organisasi dan Kepuasan Pengguna SIMDA pada Kinerja Satuan Kerja Perangkat Daerah. E-Jurnal Ekonomi Dan Bisnis Udayana, 6(6), 2587-2616.

Arisman, A., \& Fuadah, L. (2017). Analysis of Factors Affect to Organizational Performance In Using Accounting Information Systems Through Users Satisfaction and Integration Information Systems. Sriwijaya International Joumal of Dynamic Economics and Business, 1(2), 167. https://doi.org/10.29259/sijdeb.v1i2.167-180

Budyastuti, T. (2019). Factors that Influence Individual Performance in Sales Accounting Information Systems: Case Study of the Implementation of Indomaret Point of Sales. International Journal of Academic Research in Accounting, Finance and Management Science, 9(1), 142-149. https://doi.org/10.6007/IJARAFMS/v9-i1/5915

Christine, J. (2016). Pengaruh Stres Kerja Dan Konflik Kerja Terhadap Kinerja Karyawan. Jurnal Ilmiah Manajemen Bisnis, 16(1), 59-72. https://doi.org/10.1186/1758-2946-6-2

Cleary, P. (2017). Introduction to accounting information systems. In The Routledge Companion to Accounting Information Systems. https://doi.org/10.4324/9781315647210

Cornelius Pasaribu, \& Irsutami. (2015). Pengaruh Insentif Terhadap Kinerja Guru Pada Sekolah Menengah Atas Negeri (SMAN) Dengan Motivasi Sebagai Variabel Intervening. Jurnal Akuntansi, Ekonomi Dan Manajemen Bisnis Politeknik Negeri Batam, 3(1), 69-73.

Dewintha, A., Fitriyah, N., \& Rande, S. (2018). Pengaruh pemberian insentif dan motivasi terhadap kinerja pegawai di kantor camat samarinda utara. EJournal Administrative Reform, 5(3), 588-601.

Esmeray, A. (2016). The impact of accounting information systems on firm performance: Empirical evidence in Turkish small and medium sized enterprises. Internasional Journal of Business and Economic, 1(1), 1-20.

Grande, E. U., Estébanez, R. P., \& Colomina, C. M. (2011). The impact of accounting information systems (AIS) on performance measures: Empirical evidence in spanish SMEs. International Journal of Digital Accounting Research. https://doi.org/10.4192/1577-8517-v11_2

Hamdan, M. W. (2015). the Impact of Accounting Information Systems (Ais) Development Life Cycle on Its Effectiveness and Critical Success Factors. European Scientific Journal, ESJ, 8(6), 19-32. Retrieved from http://eujournal.org/index.php/esj/article/view/98

Hutabarat, Y. S. (2016). Analisis Faktor-Faktor yang Mempengaruhi Kepuasan Pengguna Sistem Informasi Akuntansi Dan Kinerja Individu Mengguna Theory Delone dan Mcleane. E-Jurnal Universitas Dipoegoro, 2015. 
Jati, K., \& Cahyana, I. G. S. (2017). Pengaruh Budaya Organisasi, Stres Kerja dan Kepuasan Kerja Terhadap Kinerja Pegawai. E-Jurnal Akuntansi Universitas Udayana, 18(2), 1689-1699. https://doi.org/10.1017/CBO9781107415324.004

Jennifer M. George, G. R. J. (2012). Understanding and Managing Organizational Behavior, 6th Edition. In Academy of Management Journal. https://doi.org/10.2307/30040635

Konečnik Ruzzier, M., Ruzzier, M., \& Hisrich, R. (2014). Value, satisfaction and customer loyalty. Marketing for Entrepreneurs and SMEs, 1(11), 21-36. https://doi.org/10.4337/9781781955970.00008

Kurniawati, C. P., Wijayanti, A., \& Masitoh, E. (2017). Pengaruh Kepuasan Pengguna Sistem Informasi Akuntansi Terhadap Kualitas Kinerja Karyawan. Journal of Seminar INACO 2017, 53(9), 1689-1699. https://doi.org/10.1017/CBO9781107415324.004

Kuvaas, B., Buch, R., \& Dysvik, A. (2018). Individual Variable Pay for Performance, Incentive Effects, and Employee Motivation. Academy of $\begin{array}{lll}\text { Management } \quad \text { Proceedings, 2018(1), } & 12393 .\end{array}$ https://doi.org/10.5465/ambpp.2018.12393abstract

Lisa Ernawatiningsih, N. P., \& Kepramareni, P. (2019). Effectiveness of Accounting Information Systems and the Affecting Factors. International Journal of Applied Business and International Management, 4(2), 33-40. https://doi.org/10.32535/ijabim.v4i2.564

Malinda, O., Dewi, F. G., \& Gamayuni, R. R. (2019). The Effect of Incentives and Non-Financial Performance on Managerial Performance. International Research Journal of Business Studies, 12(1), 41-54. https://doi.org/10.21632/irjbs.12.1.41-54

Massie, R. N., Areros, W. A., Rumawas, W., Ilmu, J., Program, A., \& Bisnis, S. A. (2018). Pengaruh Stres Kerja Terhadap Kinerja Karyawan Pada Kantor Pengelola It Center Manado. Jurnal Administrasi Bisnis, 6(2), 41.

Maziah. (2017). Pengaruh Pemberian Insentif Terhadap Kinerja Karyawan Pada PT. BNI Syariah Makassar. Jurnal UIN Alauddin Makassar, 6(2), 59-57. https://doi.org/10.1017/CBO9781107415324.004

Mukherjee, T. (2018). Sustainable Growth Rate and Its Determinants: A Study on Some Selected Companies in India. Account and Financial Management Journal, 3(01), 1290-1300. https://doi.org/10.18535/afmj/v3i1.10

Nurani. (2015). Pengaruh Pemberian Insentif Terhadap Konerja Karyawan Departemen Penjualan CV Logam Indonesia Di Tulungagung. Benefit, 2(1), 1-18.

Nurhayati, N., \& Koesdiningsih, N. (2018). The Effectiveness of Financial Accounting Information System with Approach of Organizational Culture and User Competency in Baznas North of West Java. KnE Social Sciences, 2(2), 1-20. https://doi.org/10.18502/kss.v3i10.3438

Oemar, U., \& Gangga, L. (2017). Pengaruh Stres Kerja Terhadap Kinerja Pegawai Pada Dinas Pendapatan, Keuangan Dan Aset Daerah Kabupaten Musi Manyuasin. Jurnal Ecoment Global, 2(2). https://doi.org/10.35908/jeg.v2i2.249

Putra, I. K. A. M. (2016). Agastia Maha. 2016. Pengaruh Efektivitas Penggunaan, Kepercayaan, Keahlian Pengguna, Dan Kualitas Sistem Informasi Akuntansi 
Terhadap Kinerja Karyawan Pada PT PLN (Persero) Distribusi Bali. E-Jurnal Akuntansi Universitas Udayana.

Rachmawati, R., \& Mulyani, S. (2016). The influence of the quality of management accounting information system, quality of management accounting information, and quality of service of accounting information system on the information system user satisfaction. International Journal of Economic Research, 13(3), 1-20.

Rahayu, R., Remmang, H., \& Saleh, H. (2017). Pengaruh Stres Kerja Terhadap Kinerja Karyawan Pada PT Telesindo Shop Cabang Makasar. E-Jurnal UNIBOS Makasar, 3(005), 97-111.

Rosanty, A. D., Wahyuni, M. A., \& Yuniarta, G. A. (2017). Pengaruh Teknologi Sistem Informasi Akuntansi, Kualitas Sistem Informasi dan Kepuasam Pengguna Terhadap Kinerja Organisasi Pada Dinas Kebudayaan Dan Pariwisata Kabupaten Buleleng. Jurnal Sains Dan Teknologi, 8(2), 275-287.

Santoso, F. B. (2016). Pengaruh Pemberian Insentif Dan Kompetensi Karyawan Terhadap Kinerja Karyawan PG. Madukismo Yogyakarta. E-Jurnal Universitas Negeri Yogyakarta, 4(1), 339-348.

Saputra, F., Oktaroza, M. L., \& Nurhayati, N. (2018). Pengaruh Kepuasan Pengguna Sistem Informasi Akuntansi terhadap Kinerja Karyawan pada PT Nio Farma Tbk . Bandung. E-Journal Universitas Islam Bandung, 4(1), 137-140.

Sliter, M., \& Yuan, Z. (2015). Workplace Stress. In International Encyclopedia of the Social \& Behavioral Sciences: Second Edition. https://doi.org/10.1016/B978-008-097086-8.22041-2

Veronica, V. F., Swasto, B., \& Djudi, M. (2018). Pengaruh Insentif Karyawan Terhadap Kinerja Karyawan dengan Variabel Mediator Motivasi Kerja ( Studi pada Karyawan Bagian Pabrikasi PG Kebon Agung Malang ). Jurnal Administrasi Bisnis Universitas Brawijaya, 55(2), 139-145.

Wang, G., Lee, Y., \& Ho, C. (2012). The Effects of Job Satisfaction, Organizational Commitment and Turnover intention on Organizational operating performance : as Exemplified with Employees of Listed Property Insurance Companies in Taiwan. Research in Business and Management. https://doi.org/10.1111/1464-0597.t01-1-00106

Widhawati, A., \& Damayanthi, I. G. A. E. (2018). Pengaruh Efektivitas Penggunaan Sistem Informasi Akuntansi, Budaya Kerja, dan Insentif terhadap Kinerja Karyawan. E-Jurnal Akuntansi, 24, 1301. https://doi.org/10.24843/eja.2018.v24.i02.p18

Worang, L. S., Repi, A. L., \& Dotulong, lucky o. . (2017). Pt . Bank Rakyat Indonesia (Persero) Kantor Cabang Manado Sarapung. Jurnal EMBA, 5(2), 3038-3047.

Yasri, A. C. (2016). Pengaruh Motivasi Kerja, Kepuasan Kerja dan Komitmen Organisasi Terhadap Kinerja Karyawan pada Bank Nagari. Jurnal Riset Manajemen Bisnis Dan Publik, 4(1), 1-26. 